\title{
Metrication: start learning now
}

Most Canadian foresters will be aware of the White Paper on Metric Conversion in Canada issued in January, 1970, and will have read some of the increasingly frequent articles about the metric system that are appearing in newspapers and periodicals.

The term "metrication" is generally used to mean the change from the inch-pound to the metric system of measurement. The more precise term for the metric system now is Système Internationale d'Unités (SI).

The White Paper states that "The Government believes that adoption of the metric system of measurement is ultimately inevitable - and desirable for Canada". The change, even if inevitable, will probably be influenced in fact and in timing by events in the United States which, along with Canada, is the solle major industrialized nation holdout from being on the road to metrication. The U.S. has had a Metric Study underway since 1968 that should produce a report this year. The study is to determine the impact of increasing worldwide use of the metric system on the United States and appraise the desirability and practicability of its increasing use there.

Most of us have been exposed to metric units during courses in chemistry and physics and during encounters with the optical, photographic and electronics industries, as well as with the many Canadian hospitals who have already completely converted to the metric system. However, few of us would now feel at home working completely within the SI. On this account, we will find life much easier if we become familiar with the system before it is in general use.

I had the interesting and educational experience of being a member of the group that prepared the background material from which the White Paper was developed. In the process we learned from reports and first hand accounts of the trials and tribulations of a number of countries during conversion. It was very apparent that a most important part of metrication is the process of becoming accustomed to the idea and familiar with the system. In the words of the Canadian Standards Association, in its booklet Metrication Canada, we should Start Learning Now. One means of doing this is to read some of the readily available publications on the subject.

One might start with the White Paper that may be obtained for 50 cents at Information Canada bookstores in major cities. The booklet referred to above is published by the Canadian Standards Association, 178 Rexdale Boulevard, Rexdale, Ontario, and is an excellent source of information, as is the Metric Corner of the CSA's newsletter. The British Forestry Commission
Booklet No. 27, Metric Guide to Forestry, is available from Her Majesty's Stationery Office, London, England, at three shillings ( 15 new pence), and so is the first report of the British Metrication Board Going Metric - The First Five Years $1965-69$ at 12 shillings sixpence $\left(62 \frac{1}{2}\right.$ new pence). The interest of American foresters is outlined in the Journal of Forestry for April, 1971, with an article by Zebulon W. White entitled SAF Looks at Metrication - A Debate, A Presentation, A Bibliography. This points out pros and cons from the viewpoint of foresters, and it contains a bibliography of readily available articles on the subject. Articles in the February 1969 and February 1971 Canadian Forest Industries, and in the December 1970 Canadian Pulp and Paper Industry give a Canadian viewpoint. Still another is contained in the September 18, 1970, issue of Pulp and Paper Magazine of Canada. For those who wish to pursue the British experience further, the Timber Research and Development Association (TRADA), Hughenden Valley, High Wycombe, Buckinghamshire, England, has literature that I understand is available on request.

Pointing up the desirability of becoming conversant with the metric system was the announcement last June by the Honorable Jean-Luc Pépin, Minister of Industry, Trade and Commerce, of the establishment of a Preparatory Commission for Metric Conversion. The Commission, under the chairmanship of S. M. Gossage, is to prepare, in consultation and cooperation with all interested bodies (including perhaps the (IF?), an overall program for conversion to ensure as far as possible that conversion programs in different sectors of the Canadian economy are phased and coordinated so that benefits of conversion may be achieved at minimal cost and to the best advantage to Canada.

A. B. Vincent 